\title{
THE AVARS, BYZANTIUM AND ITALY \\ A Study in Chorology and Cultural History, by Csanád Bálint
}

\section{LEVENTE SAMU}

Hungarian Archaeology Vol. 8 (2019), Issue 3, pp. 44-49, https://doi.org/10.36338/ha.2019.3.6

\section{It has been a little more than a hundred years since} József Hampel's book, the "Alterthümer" was published (1905), that one welcomes a state-of-the-art publication concerning the Avar period (7th and 8th centuries AD) in the Carpathian Basin, which discusses its subject in an entirely international context. The author strives for totality: based on a comprehensive survey of what has been available to him in the literature - regarding the types of objects, burial customs and other archaeological phenomena -, he attempts to present a synthesis, focusing on the connections of the Avars to the Mediterranean, and how these could be identified on the basis of archaeological data.

The publication of this book certainly does not come as a surprise, when taking into account the past 30-40 years of the author's career. Precisely 30 years ago, Bálint had already published a seminal volume on the archaeology of the steppe region, and that book was his first attempt to synthesize knowledge concerning the early medieval archaeology of Eastern Europe, highlighting connections between Eastern Europe and the Carpathian Basin in the Avar period (Bálint, 1989). Since the mid ' 80 s, his attention turned increasingly toward the Mediterranean region - including Byzantium (BÁLINT, 1985, pp.

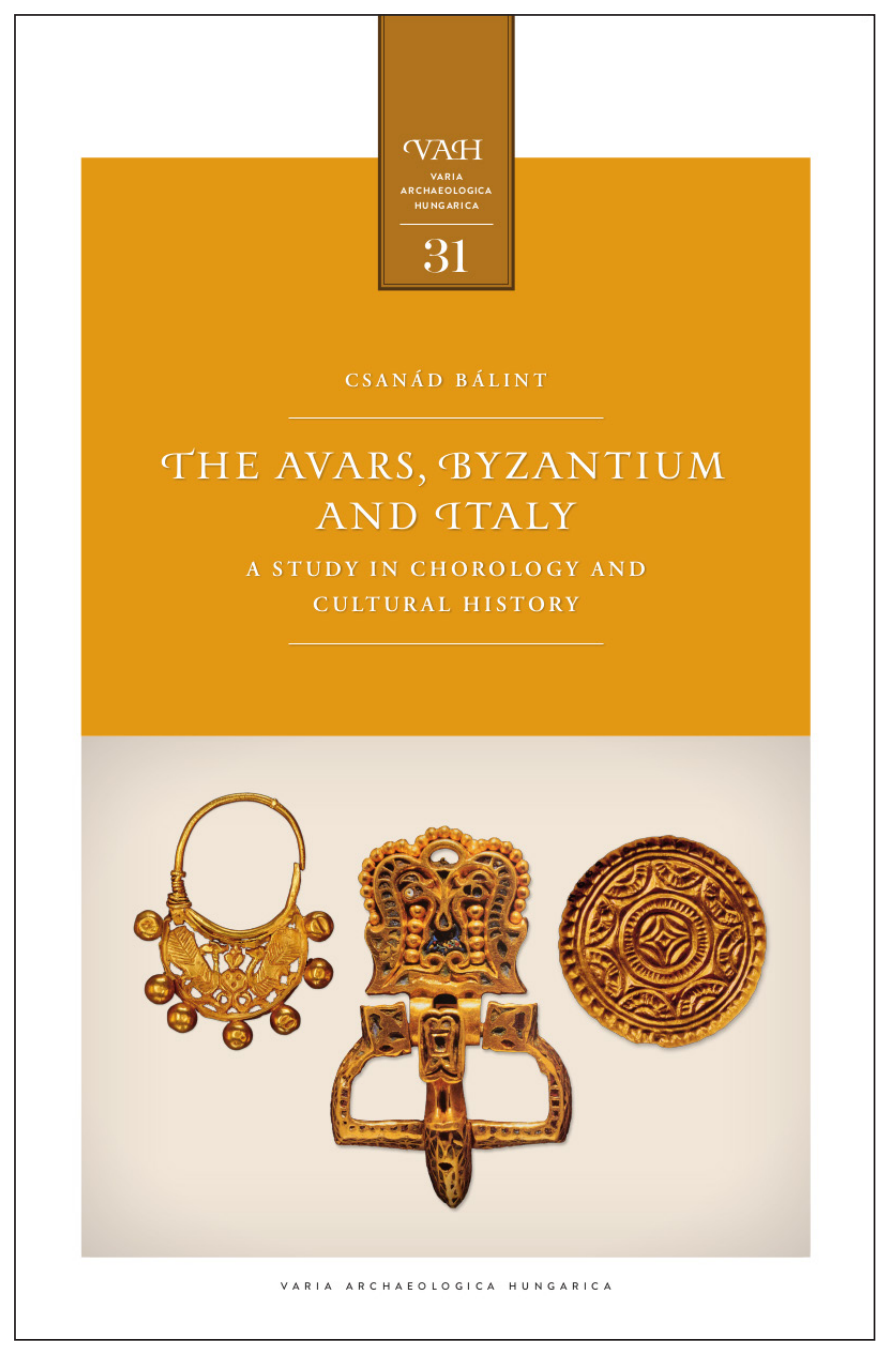
209-223). An early sign of this turn was his 1992

book about the grave in Üč Tepe (BÁLINT, 1992, pp. 309-496), ${ }^{1}$ and one has to note here his voluminous study about the migration of the Avars to the Carpathian Basin as well (BÁLINT, 1993, 195-273). In 2004, he published another book (in Hungarian), analysing the famous treasure of Nagyszentmiklós (Sânnicolau Mare, RO), the revised German edition of which was issued in 2010 (BÁLINT, 2004; 2010). In summary, the present volume is not only the result of his recent research (i.e. in the past years), but also relies on the knowledge and results of his whole career.

Among many other books and articles published during the past few years, Bálint's book also makes note of the fact that the research on the Avar period has levelled up in the past thirty years. Without giving a detailed introduction to the history of this research field, Éva Garam's study on Byzantine (or Byzantine-like) finds has to be mentioned (GARAM, 2001), as well as Tivadar Vida's published and forthcoming works (VIDA, 2000, pp. 367-377; VIDA, 2016; VIDA, 2017), which contributed to the deeper understanding of cultural exchange during the Avar period (VIDA, 2018). It is a favourable coincidence that in 2018 two significant his-

\footnotetext{
1 Later in Hungarian with a special regard to the early Avar age (BÁLINT, 1994).
} 
torical monographs have been also published on this period: one by Georgios Kardaras (2018), and the other by Walter Pohl. The latter is a revised version of his earlier work from 1988 (PoHL, 2018). Thus, one may conclude that there have been significant works published in the past 10-15 years - including archaeological excavation reports on large cemeteries -, which keep catalysing the Hungarian research as well. ${ }^{2}$

The present study is a valuable addition to the Hungarian and international research on distance trade and cultural connections in the early medieval period. Comparable studies have been produced about Italy (Keim, 2007), Sicily (Metaxas, 2009), Southern Germany (Drauschke, 2011) and there is also a growing number of publications on Late Antique and Byzantine small finds (Schulze\&Dörrlamm, 2002; 2009; Böhlendorf-Arslan\&Ricci, 2012), and Byzantine archaeology in general (Bollók, 2015, pp. 265-314). This book is significant, because it provides a perspective on the Avar period archaeology in the Carpathian Basin, within the larger international context. At once, it offers a rich insight into the basic problems of archaeological research concerning the Avars. Nonetheless, one should not expect a light reading, when choosing this book as an introduction to the archaeology of the Avar period. Bálint systematically discusses complex issues, based on methods he prefers. Although the following list is not exhaustive, the major themes include the problem of the "first generation", the "uniformity" of 8th century material culture, the technological changes and their spread, the question of regionality within the Carpathian Basin and the problem of "empty" (underpopulated?) areas, the archaeology of trade, workshops, and the movement of objects - consequently mobility -, as well as the geopolitical situation of the Carpathian Basin, its foreign connections, and cultural features characteristic specifically of the Avars.

The book is divided into ten chapters and contains also an Appendix with list of illustrations and bibliographical references of finds discussed in the text. The main goal of the author was "to offer a new perspective on the contacts with Byzantium and Italy" (p. 12). To approach this theme, Bálint applies a chorological method: four out of the ten chapters discusses the distribution of certain types of artefacts (Chapter 3, 4, 7 and 8), while other chapters raise theoretical problems (Chapter 2, 5, 6, 9 and 10). Chapter 2 and 9 provide, basically, a framework, i.e. the history of research on the one hand, (specifically focusing on the Italian connections), and a summary of archaeological observations and methodological problems on the other hand. Chapter 10 is essentially a case study, which discusses the problem of ethnic identity on the example of the Kölked A and B cemeteries (pp. 253-261).

Chapter 3 is the longest one in the book (92 pages), outlining the methodological and geographical frameworks. Therein, the author is looking for regularities in the distribution patterns of certain objects - those, which are relevant to illustrate long-distance trade connections, or on the basis of which such connections could be hypothetically argued for. Thereby, similar emphasis is given to the density of object distribution, and to the lack of objects in specific geographical areas. Based on spatial correlations - when distribution patterns seemed to overlap -, Bálint could define those regions, which possibly played a focal role in maintaining long-distance contacts and had characteristic features both in regard to material finds as well as other cultural phenomena, e.g. burial customs (pp. 30-69). The second part of the chapter discusses the possible explanations. In addition to burial customs, Bálint analyses the distribution of Byzantine coins and folding-chairs (presented as separate case studies), and the possible ways they were brought to this region. When approaching the problem of workshop activity, he is focusing on technological groups, instead of formal similarities and parallels. On the other hand, he also explores the radius of workshop activity and how commodities were accessible (pp. 84-89). As part of this problem, he analyses the movements of objects in connection to trade routes, including again case studies on the distribution of special belt mounts and ceramic types. Following the discussion of costumes, he also indulges in how archaeological finds can be interpreted as a reflection of identity (pp. 107-112).

Chapter 4 is dedicated to the theoretical and methodological problems of research on Byzantine connections. Bálint discusses first the territorial changes of the Byzantine Empire, its neighbours under Byzantine

Zsófia Rácz published a book about the Avar age goldsmith graves (RÁcz, 2014), Péter Somogyi wrote about the coin finds (Somogyi, 2014), Gergely Csiky about the polearms and edged weapons (CsiKY, 2015) etc. 
influence, then, moves on to compare the archaeological materials from the Carpathian Basin and the Eastern European territories (pp. 115-116). He touches on the question of "Byzantine" objects and dress accessories, whose spread can be observed also in Eastern Europe (pp. 118-128). A subchapter discusses belt assemblages and belt buckles, focusing particularly on their distribution patterns (dense and scarce occurrence) (pp. 129-155). One of the most important conclusions of the chapter is that the Avar society in the Carpathian Basin was an important consumer of Byzantine culture, thus, acting as intermediary "agent", influencing dress habits in East-Central and Eastern Europe, where Byzantine elements were also introduced (p. 155).

In Chapter 5, which - in our opinion - is the most important one, Bálint discusses the Italian connections, the political-geopolitical relationship between the Carpathian Basin and Italy (as a neighbouring region) (pp. 157-162). He builds a model, based on the work of Attila Kiss (KIss, 1996, pp. 300-302), integrating also the results produced in the past 20 years. A very important part of this chapter is the review and analysis of Byzantine coins, presumably originating from Italy (pp. 162-164), followed by a thorough analysis of archaeological finds from Italy. As in the works of Stephanie Keim on Italy and Southern Germany (KEIM, 2007), the provenience of these finds could not be clarified with reassuring certainty (pp. 165-173), and probably a series of case studies - complemented by scientific analyses - would be needed to provide concluding answers to these questions (BÜHLER, 2019, 203-213).

Chapter 6 deals with the problem of how Mediterranean artefacts could have arrived in the Carpathian Basin. Having surveyed the various possibilities, the author devotes many pages to the problem of trade in the Avar period, combining archaeological theories and data with the study of written sources. The analysis of archaeological data forms, apparently, the most extensive part of the chapter, where he compares the Carpathian Basin with different regions of Central Europe from the perspective of what objects occurred in the respective regions during this period and in what quantities (pp. 189-194). Chapter 7 returns the focus to the Carpathian Basin, analysing the distribution and quantity of "Byzantine" and "Byzantine-like" artefacts (pp. 196-213), including ceramics, metal and glass finds, as well as coins, jewellery and belt buckles. As T. Vida, Bálint also differentiates between "Byzantine" and "Late Antique Byzantine" types (after VIDA, 2009) (pp. 204-206).

Chapter 8 discusses the cultural importance of Mediterranean artefacts. The so called "Transdanubia phenomenon" - the remarkable differences between Transdanubia and the Great Hungarian Plane - are explained and interpreted in the light of quantitative analyses. Concerning the Transylvanian region, the discussion is significantly shorter, due to the current state of research. In case of Transdanubia (i.e. the Roman Pannonia), the chapter raises fundamental questions, such as the continuity of workshop traditions (pp. 223-224) and the problem of resettlement from the Balkan, whereby the limitations of archaeological interpretations are clearly demonstrated (pp. 226-232). Each subchapter deals with possible Western and Eastern European impacts (pp. 232-237). On the one hand, it is explained that the different geographical locations of Pannonia, the Danube-Tisza Interfluve and the Great Hungarian Plane fundamentally influenced connections to distant trade networks and on the other hand, Bálint also emphasizes the cultural background, i.e. the presence of formerly settled population groups, whose old traditions mixed with cultural influenced brought by the Avars constituted together a colourful archaeological mosaic.

In Chapter 9, the author forges a historical model to explain the Avars' disappearance in the 9th century. He emphasizes that inner cultural tensions of the Avar society in the 8th century. Although there is a sign of a shift towards agriculture, the fundamental socio-economic model of the Avar power structure remained unchanged, which inevitably led to disintegration (pp. 243-251). This narrative thread - based on cultural differences - is present throughout the whole book, as Bálint unfolds its different manifestations.

With more than 200 maps, presenting 127 types of objects, technological issues and other archaeological phenomena, this fresh volume gives a thorough insight into the cultural contacts of the Avars with the Mediterranean, focusing in particular on Italy. The comprehensive analysis offers a colourful picture about the period, and - as the author notes in his introduction -, far more questions can be raised than solutions offered. With this in mind, one should rest assured that Csanád Bálint's book will give a fresh boost to the research on the Avar period. 
Levente Samu • The Avars, Byzantium And Italy. A Study in Chorology and Cultural History, by Csanád Bálint

BIBLIOGRAPHY

BÁlint, Cs. 1985

Zur Frage der byzantinischen Beziehungen im Fundmaterial Ungarns. Archäologische Forschungen zwischen 1970 und 1984. Mitteilungen des Archäologischen Instituts der Ungarischen Akademie der Wissenschaften 14, pp. 209-223.

BÁlint, Cs. 1989

Die Archäologie der Steppe. Steppenvölker zwischen Volga und Donau vom 6. bis zum 10. Jahrhundert. Wien - Köln: Böhlau.

BÁlint, Cs. 1992

Kontakte zwischen Iran, Byzanz und der Steppe. Das Grab von Üč Tepe (Sowj. Azerbajdžan) und der beschlagverzierte Gürtel im 6. und 7. Jahrhundert. In: F. Daim, ed. Awarenforschungen I. Archaeologia Austriaca, Beiheft. Wien: Institut für Ur- und Frühgeschichte, pp. 309-496.

BÁlint, Cs. 1993

Probleme der archäologischen Forschung zur awarischen Landnahme. Vorträge und Forschungen 41 (1), pp. 195-273.

BÁLInt, Cs. 1994

Kelet, a korai avarok és Bizánc kapcsolatai. Magyar Östörténeti Könyvtár 7. Szeged: Balassi.

BÁLINT, Cs. 2004

A nagyszentmiklósi kincs. Régészeti tanulmányok. Ser. Varia Archaeologica Hungarica 16a, Budapest: Balassi.

BÁLINT, Cs. 2010

Der Schatz von Nagyszentmiklós: archäologische Studien zur frühmittelalterlichen Metallgefäßkunst des Orients, Byzanz' und der Steppe. Ser. Varia Archaeologica Hungarica 16b. Budapest: Balassi.

BollóK, Á. 2015

The Archaeology of the Byzantine State - A Non-Specialist's Approach. Antaeus 33, pp. 265-314.

BÖHLENDORF-ARSLAN, B \& RicCI, A. 2012

Byzantine Small Finds in Archaeological Contexts. Byzas 15. Istanbul: Ege Yayinlari.

BüHLER, B. 2019

Die awarisch-italischen Beziehungen aus goldschmiedtechnischer Sicht: Ein Vorbericht. Acta Archaeologica Academiae Scientiarum Hungaricae 70(1), 203-213.

CsiKY, G. 2015

Avar-age Polearms and Edged Weapons: Classification, Typology, Chronology and Technology. East Central and Eastern Europe in the Middle Ages, 450-1450, 32. Leiden - Boston: Brill. doi: https://doi. org/10.1163/9789004304543

DraUSCHKE, J. 2011

Zwischen Handel und Geschenk - Studien zur Distribution von Objekten aus dem Orient, aus Byzanz und aus Mitteleuropa im östlichen Merowingerreich. Freiburger Beiträge zur Archäologie und Geschichte des ersten Jahrtausends 14. Rahden: Marie Leidorf. 
Levente Samu • The Avars, Byzantium And Italy. A Study in Chorology and Cultural History, by Csanád Bálint

GARAM, É. 2001

Funde byzantinischer Herkunft in der Awarenzeit vom Ende des 6. Bis zum Ende des 7. Jahrhunderts. Monumenta Avarorum Archaeologica 5. Budapest: Magyar Nemzeti Múzeum.

GARAM, É. 2018

Das awarenzeitliche Gräberfeld in Zamárdi-Rétiföldek. Teil III. Monumenta Avarorum Archaeologica 12. Budapest: Magyar Nemzeti Múzeum.

HAMPEL, J. 1905

Alterthümer des frühen Mittelalters in Ungarn I-III. Braunschweig.

KaRDARAS, G. 2018

Byzantium and the Avars, 6th-9th Century AD: Political, Diplomatic and Cultural Relations. East Central and Eastern Europe in the Middle Ages, 450-1450, 51. Leiden - Boston: Brill. doi: https://doi. org/10.1163/9789004382268

KEIM, S. 2007

Kontakte zwischen dem alamannisch-bajuwarischen Raum und dem langobardenzeitlichen Italien. Archäologie Internationale 98. Rahden: Marie Leidorf.

KIss, A. 1996

Das awarenzeitlich gepidische Gräberfeld von Kölked-Feketekapu A. Monographien zur Frühgeschichte und Mittelalterarchäologie. Studien zur Archäologie der Awaren 2/5. Innsbruck: Wagner.

LÁSZLÓ, Gy. 2015

Das awarenzeitliche Gräberfeld in Csákberény-Orondpuszta. Monumenta Avarorum Archaeologica 11. Budapest: Magyar Nemzeti Múzeum 2015.

Metaxas, S. 2009

Die Materielle Kultur des byzantinischen Sizilien (6.-10. Jahrhundert). Unpublished Dissertation, Universität Wien.

MüLlER, R. 2014

Die Gräberfelder von Keszthely-Fenékpuszta, Ödenkirche-Flur. Castellum pannonicum pelsonense 5. Rahden: Marie Leidorf.

PoHL, W. 2018

The Avars. A Steppe Empire in Central Europe, 567-822. Ithaca - London: Cornell University Press. doi: https://doi.org/10.7591/9781501729409

RÁcz, Zs. 2014

Die Goldschmiedergräber der Awarenzeit. Monographien der Römisch-Germanischen Zentralmuseums 116. Mainz am Rhein: Verlag des Römisch-Germanischen Zentralmuseums.

SCHUlze-DöRRlamm, M. 2002

Byzantinische Gürtelschnallen und Gürtelbeschläge im Römisch-Germanischen Zentralmuseum. Teil I: Die Schnallen ohne Beschläg, mit Laschenbeschläg und mit festem Beschläg des 5. bis 7. Jahrhunderts. Kataloge RGZM 30, 1. Mainz am Rhein: Verlag des Römisch-Germanischen Zentralmuseums. 
Levente Samu • The Avars, Byzantium And Italy. A Study in Chorology and Cultural History, by Csanád Bálint

Schulze-DörRlamm, M. 2009

Byzantinische Gürtelschnallen und Gürtelbeschläge im Römisch-Germanischen Zentralmuseum. Teil

II. Die Schnallen mit Scharnierbeschläg und die Schnallen mit angegossenem Riemendurchzug des

7. bis 10. Jahrhunderts. Kataloge RGZM 30, 2. Mainz am Rhein: Verlag des Römisch-Germanischen

Zentralmuseums.

Somogyi, P. 2014

Byzantinische Fundmünzen der Awarenzeit in ihrem europäischen Umfeld. Dissertationes pannonicae ex Instituto Archaeologico Universitatis de Rolando Eötvös Nominatae Budapestinensis provenientes IV/2. Budapest: ELTE.

VIDA,T. 2000

Die Ziergehänge der awarenzeitlichen Frauen im Karpatenbecken. Acta Archaeologica Academiae Scientiarum Hungaricae 51, pp. 367-377.

VIDA,T. 2009

Local and Foreign Romans? The Problem of the Late Antique Population of the 6th-7th Centuries AD in Pannonia. In: D. Quast, ed. Foreigners in Early medieval Europe: Thirtheen International Studies on Early Medieval Mobility. Mainz: Römisch-Germanisches Zentralmuseum 2009, pp. 233-260.

VIDA,T. 2016

Late Antique Metal Vessels in the Carpathian Basin. Hereditas Archaeologica Hungariae 1. Budapest: Archaeolingua.

VIDA,T. 2017

Die frühbyzantinische Messingkanne mit Jagdszenen von Budakalász (Ungarn). Budapest: Institut für Archäologie - Forschungszentrum für Humanwissenschaften - Ungarische Akademie der Wissenschaften.

VIDA,T. 2018

A sztyeppei, a bizánci és a Meroving Birodalmak között. Kulturális átalakulás a Kárpát-medencében a 6-7. században. Between the Steppean, Byzantine and Merovingian Empire. Cultural changes in the Carpathian Basin to 6th-7th century AD. Thesis for the title 'Doctor of the Academy.' Budapest: Hungarian Academy of Sciences. 